\title{
Low-oxygen Atmosphere Increases Fructose 2,6-bisphosphate in Fresh-cut Carrots
}

\author{
Hisashi Kato-Noguchi ${ }^{1}$ and Alley E. Watada ${ }^{2}$ \\ Horticultural Crops Quality Laboratory, Building 002, Beltsville Agricultural Research Center, Agricultural \\ Research Service, U.S. Department of Agriculture, 10300 Baltimore Avenue, Beltsville, MD 20705
}

Additional index words. Daucus carota, glycolysis, metabolic regulation, pyrophosphate, pyrophosphate-dependent:phosphofructokinase

\begin{abstract}
This study was undertaken to determine the effect of low- $\mathrm{O}_{2}$ atmosphere on the concentration of fructose 2,6bisphosphate (Fru-2,6-P $)$, which can activate the enzyme pyrophosphate-dependent:phosphofructokinase (PPi-PFK) to catalyze the reaction from fructose 6-phosphate to fructose 1,6-bisphosphate (Fru-1,6-P $)$. Fru-2,6-P, remained unchanged in carrot (Daucus carota $\mathrm{L}$.) root shreds stored under air, but it increased 3.0- and 5.3-fold at $2 \%$ and $0.5 \% \mathrm{O}_{2}$ atmosphere, respectively, at $5 \mathrm{C}$, and the increases were almost twice as great at $15 \mathrm{C}$. The concentration of $\mathrm{PPi}$ ranged from

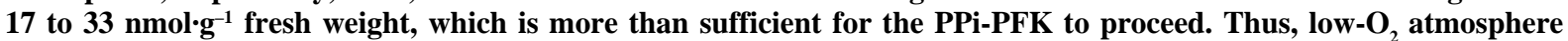
appeared to hasten glycolysis of carrot shreds by increasing Fru-2,6-P, which activated PPi-PFK toward glycolysis.
\end{abstract}

At least three pathways are involved in the interconversion of fructose 6-phosphate (Fru-6-P) and fructose 1,6-bisphosphate (Fru-1,6- $\mathrm{P}_{2}$ ), and this interconversion has been recognized as an important regulatory site for the flow of carbon between carbohydrate storage products (sugar and starch) and carbohydrate use (Black et al., 1987; Solomos, 1988). The reactions are catalyzed essentially by two irreversible enzymes: ATP-dependent : phosphofructokinase (conversion of Fru-6-P to Fru-1,6- $\mathrm{P}_{2}$ ) and fructose 1,6-bisphosphatase (FBPase, conversion of Fru-1,6- $\mathrm{P}_{2}$ to Fru6-P). A third enzyme, pyrophosphate-dependent : phosphofructokinase (PPi-PFK), readily reversible in vitro, catalyzes the interconversion of Fru-6-P and pyrophosphate (PPi) to Fru-1,6- $\mathrm{P}_{2}$ and inorganic phosphate (Pi) (Black et al., 1987; Nielsen, 1994).

Fructose 2,6-bisphosphate (Fru-2,6- $\mathrm{P}_{2}$ ) is a regulatory metabolite that makes an important contribution to the regulation of carbohydrate metabolism in different types of eukaryotic organism (Hers et al., 1982; Ueda et al., 1982). In plants, Fru-2,6- $\mathrm{P}_{2}$ promotes glycolysis and restricts gluconeogenesis by activating PPi-PFK and inhibiting FBPase, respectively (ap Rees and Dancer, 1987; Hatzfeld et al., 1989). Fru-2,6- $\mathrm{P}_{2}$ is present in plant tissues in significant amounts, and its concentration fluctuates depending on physiological or environmental conditions such as flooding, wounding, and photosynthetic light (ap Rees and Dancer, 1987; Paz et al., 1985; Van Schaftingen and Hers, 1983). The glycolytic form of PPi-PFK, that is induced by Fru-2,6- $\mathrm{P}_{2}$, requires PPi as a substrate for the reaction (Smyth and Black, 1984).

Although much research on controlled and modified atmosphere has been directed toward determining optimum conditions for various fruits and vegetables (Hardenburg et al., 1990), little is known about the mode of action of $\mathrm{O}_{2}$ and $\mathrm{CO}_{2}$ on respiratory metabolism of these commodities (Kader, 1986). The contribution of Fru-2,6- $\mathrm{P}_{2}$ to respiratory metabolism in harvested plant organs under controlled or modified atmosphere is not clear.

\footnotetext{
Received for publication 28 July 1995. Accepted for publication 16 Nov. 1995. Use of a company or product name by U.S. Dept. of Agriculture does not imply approval or recommendation of the product to the exclusion of others that also may be suitable. We gratefully acknowledge Willard Douglas for excellent technical assistance. The cost of publishing this paper was defrayed in part by the payment of page charges. Under postal regulations, this paper therefore must be hereby marked advertisement solely to indicate this fact.

${ }^{1}$ Permanent address: Dept. of Bioresource Science, Faculty of Agriculture, Kagawa Univ., Miki-cho, Kagawa 761-07, Japan.

${ }^{2}$ To whom reprint requests should be addressed.
}

We previously observed that activity of the reversible enzyme PPi-PFK increased with the accumulation of Fru-1,6- $\mathrm{P}_{2}$ in carrot shreds held under low- $\mathrm{O}_{2}$ atmosphere (Kato-Noguchi and Watada, 1996). In this report, we show that low $\mathrm{O}_{2}$ increased the level of Fru-2,6- $\mathrm{P}_{2}$, which in the presence of adequate supply of PPi, PPiPFK was activated toward glycolysis.

\section{Materials and Methods}

Plant materials and treatments. Carrot roots were purchased from a local wholesale distributor (Jessup, Md.). The carrots were shredded (about $50 \mathrm{~mm}$ long, $5 \mathrm{~mm}$ wide, and $4 \mathrm{~mm}$ thick) and stored in 3.8-liter glass jars ( $100 \mathrm{~g}$ fresh weight per jar, at least six jars for each sampling date) at 5 and $15 \mathrm{C}$ as described previously (Kato-Noguchi and Watada, 1996). A stream of $0.5 \%$ or $2 \% \mathrm{O}_{2}$ (balance $\mathrm{N}_{2}$ ), or air was metered through the jar at a rate of 10 $\mathrm{ml} \cdot \mathrm{min}^{-1}$ at $5 \mathrm{C}$ and $15 \mathrm{ml} \cdot \mathrm{min}^{-1}$ at $15 \mathrm{C}$, which was sufficient to keep $\mathrm{CO}_{2}$ accumulation below $0.3 \%$ and to measure respiration (KatoNoguchi and Watada, 1996).

To quantify Fru-2,6- $\mathrm{P}_{2}, \mathrm{PPi}, \mathrm{Pi}$, and ATP, carrot shreds for initial sample (day 0) were frozen in liquid $\mathrm{N}_{2}$ within $5 \mathrm{sec}$ after shredding and stored at $-80 \mathrm{C}$ until analysis. One jar for each treatment was removed from storage on day 1, 3, 6, and 9, and carrot shreds were frozen as same manner as initial sample.

Measuring Fru-2,6- $P_{2}$. To measure content of Fru-2,6- $\mathrm{P}_{2}$, the frozen carrot shreds ( $3 \mathrm{~g}$ fresh weight equivalent) were placed in a mortar containing liquid $\mathrm{N}_{2}$ and ground to a fine powder using a pestle. Before the liquid $\mathrm{N}_{2}$ had evaporated, $10 \mathrm{ml}$ of ice-cold 50 $\mathrm{mm} \mathrm{NaOH}$ was added to the sample and homogenized. The homogenate was kept for $30 \mathrm{~min}$ at $0 \mathrm{C}$ with occasionally shaking. The mixture was centrifuged at $10,000 \times g$ for $10 \mathrm{~min}$ at $0 \mathrm{C}$. The supernatant was heated for $5 \mathrm{~min}$ at $0 \mathrm{C}$, cooled in ice, and centrifuged again at $10,000 \times g$ for $5 \mathrm{~min}$. The resulting supernatant was used to quantify Fru-2,6- $\mathrm{P}_{2}$.

Quantification was carried out spectrophotometrically by monitoring the oxidation of NADH at $340 \mathrm{~nm}$ for $15 \mathrm{~min}$ at $30 \mathrm{C}$ in the following 1-ml reaction mixture according to Van Schaftingen and Hers (1983): $50 \mathrm{~mm}$ Tris-acetate ( $\mathrm{pH}$ 8.0), 2 mm magnesium acetate, 5 mм Fru-6-P, 0.15 mм NADH, 0.5 mм PPi-tetrasodium, 1.2 units of aldolase, 1.8 units of glycerol-3-phosphate dehydrogenase, 7.5 units of triosephosphate isomerase, 0.5 units of PPi-PFK (Sigma Chemical Co., F-7006), and up to $0.1 \mathrm{ml}$ of the extract. The assay was started by adding PPi-tetrasodium after $5 \mathrm{~min}$ 


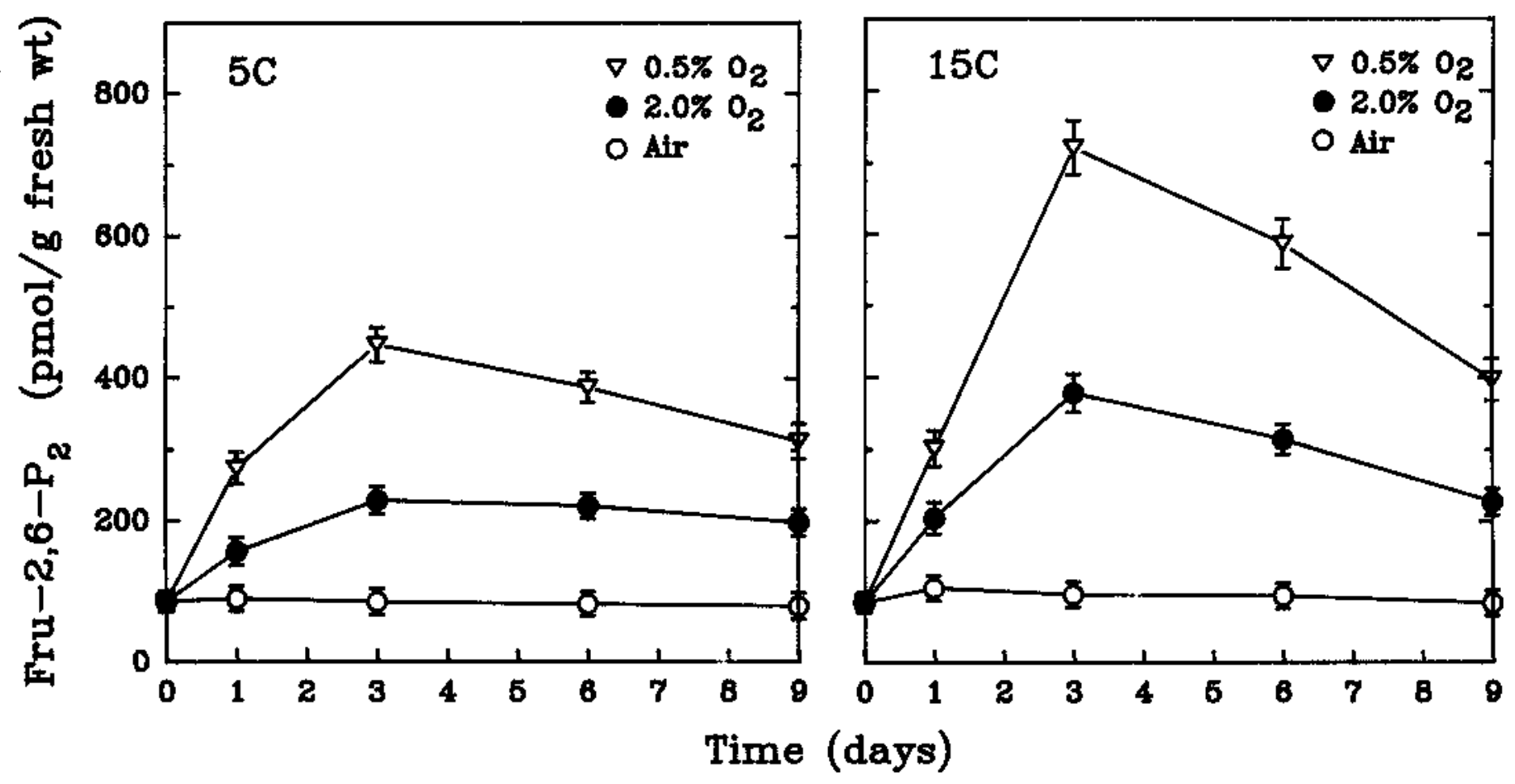

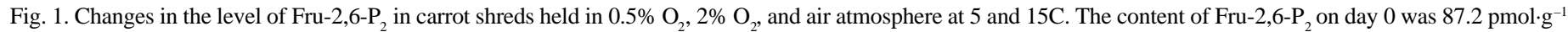
fresh weight. Mean \pm SE from three experiments with at three assays for each determination.

preincubation. The amount of Fru-2,6- $\mathrm{P}_{2}$ in each sample was calculated by comparing the extent of activation with that induced by known amounts of standard Fru-2,6- $\mathrm{P}_{2}$. The recovery of Fru2,6- $\mathrm{P}_{2}$ added to the extraction medium containing carrot shreds before homogenation exceeded $90 \%$.

Measuring PPi, $\mathrm{Pi}$, and ATP. Tissue powder ( $5 \mathrm{~g}$ fresh weight equivalents) was prepared as described above and homogenized with $10 \mathrm{ml}$ of ice-cooled $0.45 \mathrm{~N} \mathrm{HClO}_{4}$ at $0 \mathrm{C}$ for $30 \mathrm{~min}$ with occasional shaking. Insoluble materials in the homogenate were removed by centrifugation at $30,000 \times g$ for $15 \mathrm{~min}$ at $0 \mathrm{C}$. The supernatant was neutralized to $\mathrm{pH} 7.0-7.5$ with $5 \mathrm{~N} \mathrm{~K}_{2} \mathrm{CO}_{3}$. The precipitated potassium chlorate was removed by centrifugation $(30,000 \times g, 5 \mathrm{~min})$ and the supernatant was used for analyzing PPi, Pi, and ATP. PPi was determined immediately, whereas samples used for Pi and ATP were stored at -80C until analysis.

$\mathrm{PPi}, \mathrm{Pi}$, and ATP were quantified spectrophotometrically by monitoring the oxidation/reduction of NADH/NAD and NADP at $30 \mathrm{C}$ using 25 to $50 \mu \mathrm{l}$ of the extract containing in the following 1$\mathrm{ml}$ reaction mixture: $50 \mathrm{~mm}$ Tris-acetate $(\mathrm{pH} 8.0), 2 \mathrm{~mm}$ magnesium acetate, $2 \mu \mathrm{M}$ Fru-2,6-P 2,5 mм Fru-6-P, 0.15 mм NADH, 1.2 units of aldolase, 2 units of glycerol-3-phosphate dehydrogenase, 7.5 units of triosephosphate isomerase, 0.5 units of PPi-PFK for PPi (Van Schaftingen and Hers, 1983); $100 \mathrm{~mm}$ triethanolamine (pH 7.6), 1 mMEDTA, 2 mm MgCl, 1.3 mm NAD, 10 mm glucose, $1 \mathrm{~mm}$ ADP, $0.5 \mathrm{~mm}$ Fru-1,6- $\mathrm{P}_{2}, 2$ units of aldolase, 9 units of glyceraldehyde-3-phosphate dehydrogenase, 3 units of hexokinase, and 16 units of phosphoglycerate kinase for $\mathrm{Pi}$ (Cornell et al., 1979); $100 \mathrm{~mm}$ triethanolamine ( $\mathrm{pH} 7.6), 4 \mathrm{~mm} \mathrm{MgCl}_{2}, 2 \mathrm{~mm}$ NADP, 2 mm glucose, 3.5 units of glucose-6-phosphate dehydrogenase, and 2.8 units of hexokinase for ATP (Mohanty et al., 1993).

The overall recovery of $\mathrm{PPi}, \mathrm{Pi}$, and ATP added to the extraction medium containing carrot shreds before homogenation was $88 \% \pm$ $4 \%, 91 \% \pm 2 \%$, and $89 \% \pm 3 \%$, respectively, as calculated from five replications of the test run with pure PPi, Pi, and ATP.
Three entirely separate experiments were conducted, and determination was replicated at least twice in each experiment. All enzymes were purchased from Sigma Chemical Co.

\section{Results and Discussion}

The Fru-2,6- $\mathrm{P}_{2}$ content was low on day 0 and did not change with samples stored in air (Fig. 1). The content increased under $0.5 \%$ and $2 \% \mathrm{O}_{2}$ atmosphere, and the increase was greater at the lower $\mathrm{O}_{2}$ and higher storage temperature. By day 3, Fru-2,6- $\mathrm{P}_{2}$ increased 3.0- and 5.3-fold with samples in $2 \% \mathrm{O}_{2}$ and $0.5 \% \mathrm{O}_{2}$ at $5 \mathrm{C}$, and 4.0- and 7.8-fold with samples in $2 \% \mathrm{O}_{2}$ and $0.5 \% \mathrm{O}_{2}$ at $15 \mathrm{C}$, respectively, compared with samples in air. After day 3 , the content began to decrease under $0.5 \% \mathrm{O}_{2}$ at $5 \mathrm{C}$ and under $0.5 \%$ and $2 \% \mathrm{O}_{2}$ at $15 \mathrm{C}$. The pattern of changes in the level of Fru-2,6- $\mathrm{P}_{2}$ was similar to those of PPi-PFK activity and Fru-1,2-P 2 content (KatoNoguchi and Watada, 1996). A similar correlation between content of Fru-2,6- $\mathrm{P}_{2}$ and activity of PPi-PFK is found in rice seedlings after making tissue anoxia (Mertens et al., 1990).

The content of Fru-2,6- $\mathrm{P}_{2}$ in samples under low $\mathrm{O}_{2}$ ranged from 0.15 to $0.78 \mathrm{nmol} \cdot \mathrm{g}^{-1}$ fresh weight. All available evidence strongly suggests that Fru-2,6- $\mathrm{P}_{2}$ is confined to the cytosol in plants (ap Rees and Dancer, 1987; Paz et al., 1985). Assuming the plant cell cytoplasm is $10 \%$ of the cell volume (Black et al., 1987), then the concentration of Fru-2,6- $\mathrm{P}_{2}$ is likely to be in the range 1.5 to $7.8 \mu \mathrm{M}$. This concentration is more than sufficient to activate PPi-PFK (Black et al., 1987; Kombrink et al., 1984; Stitt, 1989). The increase of Fru-2,6- $\mathrm{P}_{2}$ in response to low $\mathrm{O}_{2}$ atmosphere may be important in regulating glycolysis in carrot shreds.

Although PPi-PFK is a reversible enzyme and can catalyze the reaction between Fru-6-P and Fru-1,6- $\mathrm{P}_{2}$, activation by Fru-2,6- $\mathrm{P}_{2}$ dramatically increases the $\mathrm{V}_{\max }$ of PPi-PFK activity and increases the affinity of PPi-PFK for Fru-6-P (Black et al., 1987; Stitt, 1990). Accordingly, it has been proposed that Fru-2,6- $\mathrm{P}_{2}$ can be viewed as a glycolytic signal (Stitt, 1990; Van Schaftingen, 1987). Of 
Table 1. Content of PPi, Pi, and ATP in carrot shreds held in $0.5 \% \mathrm{O}_{2}, 2 \% \mathrm{O}_{2}$, and air atmosphere at 5 and $15 \mathrm{C}$.

\begin{tabular}{|c|c|c|c|c|}
\hline \multirow{2}{*}{\multicolumn{2}{|c|}{ Treatment }} & \multicolumn{3}{|c|}{ Content $\left(\mathrm{nmol} \cdot \mathrm{g}^{-1} \text { fresh } \mathrm{wt}\right)^{2}$} \\
\hline & & PPi & $\mathrm{Pi}$ & ATP \\
\hline \multicolumn{2}{|c|}{ 0 Days (initial) } & $33.4 \pm 3.4$ & $5410 \pm 430$ & $89.7 \pm 8.4$ \\
\hline & Air, 3 days & $31.3 \pm 2.1$ & $7250 \pm 820$ & $84.5 \pm 6.3$ \\
\hline & Air, 6 days & $29.2 \pm 1.8$ & $8320 \pm 690$ & $79.2 \pm 7.3$ \\
\hline & $2 \%, 3$ days & $27.5 \pm 2.1$ & $6820 \pm 870$ & $69.6 \pm 6.8$ \\
\hline & $2 \%, 6$ days & $21.6 \pm 1.9$ & $7620 \pm 940$ & $59.5 \pm 5.9$ \\
\hline & $0.5 \%, 3$ days & $23.7 \pm 2.4$ & $6420 \pm 690$ & $58.7 \pm 7.5$ \\
\hline & $0.5 \%, 6$ days & $18.2 \pm 2.1$ & $6980 \pm 960$ & $46.3 \pm 6.9$ \\
\hline \multirow[t]{6}{*}{$15 \mathrm{C}$} & Air, 3 days & $28.2 \pm 2.4$ & $7830 \pm 860$ & $75.6 \pm 7.9$ \\
\hline & Air, 6 days & $24.8 \pm 1.7$ & $8670 \pm 790$ & $62.3 \pm 6.6$ \\
\hline & $2 \%, 3$ days & $25.4 \pm 1.8$ & $7520 \pm 850$ & $55.1 \pm 6.1$ \\
\hline & $2 \%, 6$ days & $18.3 \pm 1.6$ & $8120 \pm 920$ & $51.5 \pm 6.8$ \\
\hline & $0.5 \%, 3$ days & $21.4 \pm 2.5$ & $7210 \pm 860$ & $52.4 \pm 5.7$ \\
\hline & $0.5 \%, 6$ days & $17.5 \pm 2.6$ & $7880 \pm 760$ & $43.7 \pm 4.5$ \\
\hline
\end{tabular}

${ }^{\mathrm{z}}$ Mean \pm SE from three experiments with at least two assays for each determination.

course, Fru-2,6- $\mathrm{P}_{2}$ also is now known to influence the activity of several other enzymes in plant sugar metabolism, such as the cytoplasmic FBPase and gluconate dehydrogenase (ap Rees and Dancer, 1987). PPi-PFK is more sensitive to Fru-2,6-P than other enzymes, hence it is a primary Fru-2,6- $\mathrm{P}_{2}$ target site (ap Rees and Dancer, 1987; Stitt, 1990).

For PPi-PFK to function in the glycolytic direction, an adequate pool of PPi must be present as a substrate (Smyth and Black, 1984). We found the PPi pool, which ranged from 17.5 to $33.4 \mathrm{nmol} \cdot \mathrm{g}^{-1}$ fresh weight, to be at least $35 \%$ to $40 \%$ of the size of the ATP pool (Table 1). The contents of PPi in other plant tissues were 5 to 39 nmol.g ${ }^{-1}$ fresh weight (Kesy and Kowalczyk, 1987; Smyth and Black, 1984). Contents of Pi in carrot shreds (Table 1) are comparable to those reported for other plants (ap Rees et al., 1985; Edwards et al., 1984). The PPi concentration in carrot shreds was estimated to be 17.5 to $33.4 \mu \mathrm{M}$ with the assumption that $1 \mathrm{~g}$ fresh weight of tissue is equal to $1 \mathrm{ml}$. The $\mathrm{K}_{\mathrm{m}}$ for PPi of partially purified plant PPi-PFK is 10 to $20 \mu \mathrm{M}$ (Kombrink et al. 1984; Smyth and Black, 1984). Thus, the PPi concentration in carrot shreds exceeds the $\mathrm{K}_{\mathrm{m}}$ values of PPi-PFK for PPi. These results suggest that PPi is present in carrot shreds as an appreciable pool and its presence provides the phosphate-donating substrate and the energy source for PPi-PFK.

These results indicate that low $\mathrm{O}_{2}$ caused an increase in the level of Fru-2,6- $\mathrm{P}_{2}$, which in the presence of adequate supply of PPi, PPiPFK was activated toward glycolysis. Glycolysis has been shown to be accelerated in many other plants when $\mathrm{O}_{2}$ is limiting and the glycolytic pathway was considered to replace the Krebs cycle as the main source of energy (Kennedy et al., 1992). The carrot shreds apparently increased glycolysis by activating the PPi-PFK pathway because ATP-PFK activity remained unchanged under low $\mathrm{O}_{2}$ (Kato-Noguchi and Watada, 1996). The activity of ATP-PFK may have been restricted and could not be accelerated due to reduced supply of ATP, which had decreased by $30 \%$ under low $\mathrm{O}_{2}$ (Table 1). Black et al. (1987) describes how the reaction catalyzed by PPiPFK conserves energy compared to that catalyzed by ATP-PFK. Thus, when $\mathrm{O}_{2}$ became limiting, carrot shreds perhaps increased glycolysis as a source of energy and activated a pathway that conserved energy.

\section{Literature Cited}

ap Rees, T., J.H. Green, and P.M. Wilson. 1985. Pyrophosphate: fructose 6-phosphate 1-phosphotransferase and glycolysis in non-photosynthetic tissues of higher plants. Biochem. J. 227:299-304. ap Rees, T. and J.E. Dancer. 1987. Fructose-2,6-bisphospate and plant respiration, p. 341-350. In: A.L. Moore and R.B. Beechey (eds.). Plant mitochondria: Structural, functional, and physiological aspects. Plenum Press, New York.

Black. C.C., L. Mustardy, S.S. Sung, P.P. Kormanik, D.-P. Xu, and N. Paz. 1987. Regulation and roles for alternative pathways of hexose metabolism in plants. Physiol. Plant. 69:387394.

Cornell, N.W. M.G. Leadbetter and R.L. Veech. 1979. Modifications in the enzymatic assay for inorganic phosphate. Anal. Biochem. 95:524-526.

Edwards, J., T. ap Rees. P.M. Wilson and S, Morrell. 1984. Measurement of the inorganic pyrophosphate in tissues of Pisum sativum L. Planta 162:188-191.

Hardenburg, R.E., A.E. Watada, and C.Y. Wang. 1990. The commercial storage of fruits, vegetables, and florist and nursery stocks. Agr. Hdbk66. USDA/ARS. U.S. Government Printing Office, Washington, D.C.

Hatzfeld, W.-D., J.E. Dancer, and M. Stitt. 1989. Direct evidence that pyrophosphate:fructose6-phosphatephosphotransferase can act as a glycolytic enzyme in plants. FEBS Lett. 254:215-218.

Hers, H.-G., L. Hue, and E. Van Schaftingen. 1982. Fructose 2,6-bisphosphate. Trends Biochem. Sci. 7:329-331.

Kader, A.A. 1986. Biochemical and physiological basis for effects of controlled and modified atmospheres on fruits and vegetables. Food Technol. 40:99-104.

Kato-Noguchi, H. and A.E. Watada. 1996. Regulation of glycolytic metabolism in lightly processed carrots under low oxygen atmosphere. J. Amer. Soc. Hort. Sci. (In press.)

Kennedy, R.A., M.E. Rumpho, and T.C. Fox. 1992. Anaerobic metabolism on plants. Plant Physiol. 100:1-6.

Kesy, J. and S. Kowalczyk. 1987. Comparison of the activity of the enzymes participating in fructose-6-phosphate/fructose-1,6-bisphosphate interconversion during early stages of mung bean (Phaseolus coccineus L.) development. Measurement of pyrophosphate and fructose2,6-bisphosphate content

J. Plant Physiol. 127:411-421.

Kombrink, E., N.J. Kruger, and H. Beevers. 1984. Kinetic properties of pyrophosphate: fructose-6-phosphate phospho-transferase from germinating castor bean endosperm. Plant Physiol. 74:395-401.

Mertens, E., Y. Larondelle, and H.-G. Hers. 1990. Induction of pyrophosphate:fructose 6phosphate 1-phosphotransferase by anoxia in rice seedlings. Plant Physiol. 93:584-587.

Mohanty, B., P.M. Wilson, and T. ap Rees. 1993. Effects of anoxia on growth and carbohydrate metabolism in suspension cultures of soybean and rice. Phytochemistry 34:75-82.

Nielsen, T.H. 1994. Pyrophosphate:fructose-6-phosphate 1-phospho-transferase from barley seedlings. Isolation, subunit composition and kinetic characterization. Physiol. Plant. 92:311321.

Paz, N., D.-P. Xu, and C.C. Black. 1985. Rapid oscillations in fructose 2,6-bisphosphate levels in plant tissues. Plant Physiol. 79:1133-1136.

Smyth, D.A. and C.C. Black. 1984. Measurement of the pyrophosphate content of plant tissues. Plant Physiol. 75:862-864.

Solomos, T. 1988. Respiration in senescing plant organs: Its nature, regulation, and physiological significance, p. 111-145. In: L.D. Nooden and A.C. Leopold (eds.). Senescence and aging in plants. Academic Press, San Diego.

Stitt, M. 1989. Product inhibition of potato tuber pyrophosphate: fructose-6-phosphate phosphotransferase by phosphate and pyrophosphate. Plant Physiol. 89:623-633.

Stitt, M. 1990. Fructose-2,6-bisphosphate as a regulatory molecule in plants. Annu. Rev. Plant Physiol. Plant Mol. Biol. 41:153-185.

Ueda. K., E. Furuya, C.S. Richards, and M. Yokoyama. 1982. Fructose-2,6-P 2 , chemistry and biological function. Mol. Cell. Biochem. 48:97-120.

Van Schaftingen, E. and H.-G. Hers. 1983. Fructose 2,6-bisphosphate in relation with the resumption of metabolic activity in slices of Jerusalem artichoke tubers. FEBS Lett. 164:195-200.

Van Schaftingen, E. 1987. Fructose 2,6-bisphosphate. Adv. Enzymol. Relat. Areas Mol. Biol. 59:315-395. 